\title{
Assessment and Monitoring Damage by Coraebus florentinus (Coleoptera: Buprestidae) in Mediterranean Oak Forests
}

\author{
Ana M. Cárdenas, Patricia Gallardo \\ Department of Zoology, University of Córdoba, Córdoba, Spain \\ Email: ba1cataa@uco.es
}

How to cite this paper: Cárdenas, A.M. and Gallardo, P. (2018) Assessment and Monitoring Damage by Coraebus florentinus (Coleoptera: Buprestidae) in Mediterranean Oak Forests. Open Journal of Ecology, 8, 324-338.

https://doi.org/10.4236/oje.2018.85020

Received: March 29, 2018

Accepted: May 25, 2018

Published: May 28, 2018

Copyright ( 92018 by authors and Scientific Research Publishing Inc. This work is licensed under the Creative Commons Attribution International License (CC BY 4.0).

http://creativecommons.org/licenses/by/4.0/

\begin{abstract}
Coraebus florentinus (Herbst) is a wood borer beetle that damages the most abundant Quercus species making up the Mediterranean forests. Damage is due to the feeding activity of the larvae which cuts the sap flow into the branch where it develops, drying it. In the last decades, the geographical range and the damage records of this species have expanded northwardly as a result of the climate global change since warmer conditions favor higher reproduction and quicker development of this species. On this paper, historical series of data after ten years evaluating damages by $C$. florentinus in Hornachuelos Natural Park (Southern Spain) are analyzed under the perspective of the environmental temperature increase linked to the global climate change. The assessment was done between 2007 and 2017, in two sampling plots of Mediterranean mixed-oak forests where holm and cork oaks are the predominant tree species. Results show that the infestation levels of this species at the beginning of the assessment period were higher than those described previously in the nineties and that they increased progressively during the monitoring time. The results also agree with the expansion of its distribution areas noticed in other areas of Europe. The foreseeable rising of damages of $C$. florentinus is discussed, at greater scale, under the perspective of future scenery of environmental warming and oaks decaying by losing fitness due to higher soil aridity.
\end{abstract}

\section{Keywords}

Buprestidae, Coleoptera, Coraebus florentinus, Damage, Mediterranean, Monitoring, Oak Forests

\section{Introduction}

The environmental degradation of the Mediterranean forests is an increasingly 
considered question when designing the management measures dealing with biodiversity or climate change [1]. The challenge of guaranteeing natural resources for future implies sustainable management of the forests, protection of relic preserved spaces and restoration of disturbed zones [2]. In agreement with these statements, the Habitat Directive (92/43/EEC, 1992), relative to the conservation of unmanaged habitats and of wild fauna and flora, established the obligation of taking all the compensatory measures necessaries to ensure the overall coherence of Nature 2000 Net (European Ecological Network for Conservation of Biodiversity [3]). Accordingly, the construction of the Breña dam (completed in 2008 in the Guadiato River basin, southern Iberian Peninsula) required the implementation of an actions' package to offset the environmental disturbance caused by flooding part of a nature reserve and by the construction of the infrastructure itself [4]. Being part of these actions, between 2007 and 2017, the research project titled "Study and Monitoring Plan of wood borer beetles damaging Quercus species" has been developed, including the assessment and monitoring of damage caused by Coraebus florentinus (Herbst, 1801).

C. florentinus is a xylophagous jewel beetle (Coleoptera: Buprestidae), which bores the branches of different species of Quercus [5]. Because of its affinity by holm (Quercus ilex, Linné 1753) and cork oaks (Q. suber, Linné 1753), this insect is mainly distributed in the Mediterranean forests where these tree species predominate [6].

The damage is due to the feeding activity of larvae, which makes longitudinal and annular galleries under the bark of terminal branches, interrupting the sap flow and drying the branches in which the insect completes its development [7]. The reduction in the number of healthy branches results in a progressive decay and loss of vigor of the tree [8]. The symptoms for recognizing damage caused by this species are easily identifiable and widely described in literature [5] [9] [10] [11] [12].

In several countries from the Mediterranean basin (Italy, Spain and Portugal) it has been detected that populations of the buprestid are growing at the same time that the damages they produce are increasing [8]. These processes are linked, in addition to other factors, to the progressive abandonment of pruning in the Mediterranean oak forests [13], in spite of being the most effective control method for some pests like this case [6] [14].

More recently, it has been noted that the geographical range of this species is also extended towards Center-Europe and that its damages have been north-worldly expanded. This may be explained because $C$. florentinus, as a thermophilous species [15] [16], is favored by the environmental warming linked to the global change [17] since increasing temperature rises the reproduction rate and quickens development [5].

Even though it is catalogued as a primary pest of medium importance [14], the combined effect of increasing populations, expanding geographical distribution and intensification of damages, have determined the inclusion of $C$. floren- 
tinus among the wood borer species involved in oak declines in Europe [18].

On the other hand, the direct influence of climate on the oaks species making up the mixed Mediterranean forest has been analyzed from different perspectives: chorological [19], eco-physiological [20] [21] and phytosanitary [22]. However, other more indirect and long-term consequences should also be considered, such as forestalling the disturbing effects of climate change on phytophages, xylophages or pathogens [23]. The increase in environmental temperature affects phenology, life cycles and distribution of phytophagous insects [24], as well as synchronization of insect-plant interactions [25] [26]. A rise in temperature may, therefore, favor the development of thermophiles pest, intensifying their effects or widening their distribution as it has been evidenced for $C$. florentinus [17].

Measuring the success of management and restoration requires having a survey plan that allows assessing environmental changes in space and time [2], including the effect of the climate change on the pests.

Under this framework of reference, this research was scheduled, whose main objective was to assess and to monitor the damages caused by $C$. florentinus, during a ten years period and to analyze them under the perspective of the environmental temperature increase linked to the global climate change.

\section{Material and Methods}

\subsection{The Study Area}

Field work was carried out in a natural space belonging to the Hornachuelos Natural Park (southern Iberian Peninsula; Figure 1) and is included in the area of environmental improvement linked to the construction of the Breña dam [4]. The climate is typically Mediterranean (annual rainfall between $500-800 \mathrm{~mm}$; average annual temperature of $17^{\circ} \mathrm{C}$ approx.). The altitude ranges from 250 to $725 \mathrm{~m}$ (a.s.l.) [27]. Lithologically, palaeozoic metamorphic rocks predominate;

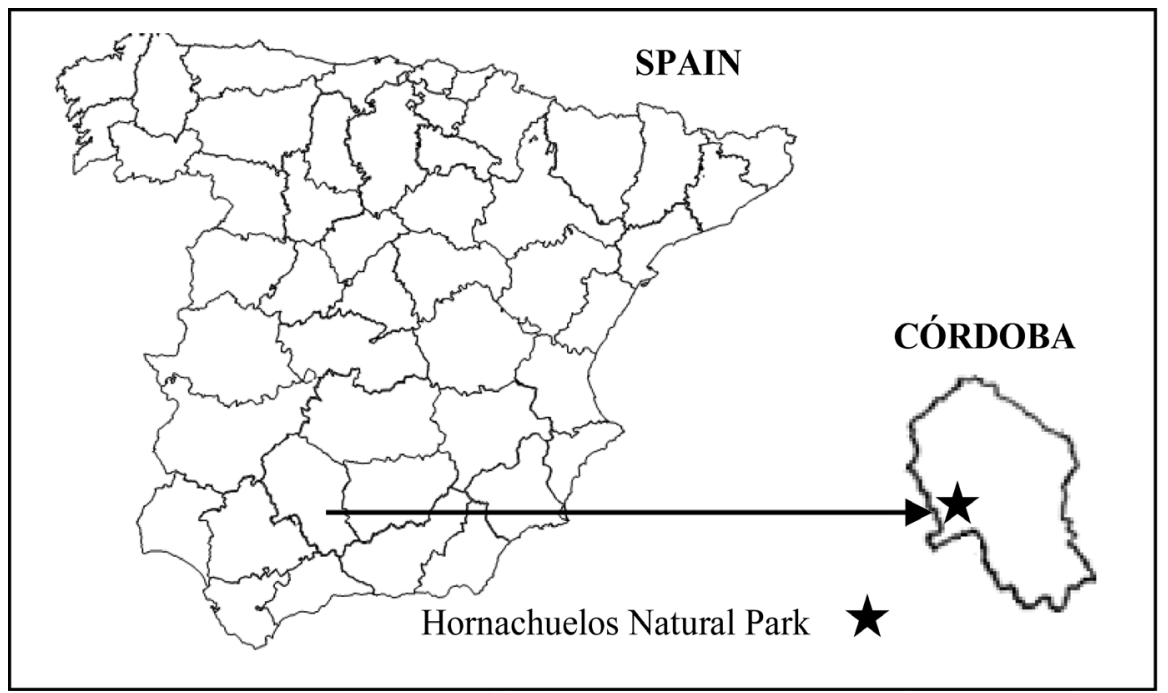

Figure 1. Location of the research area. 
particularly, quartzite, slates, or semiacidic intrusive rocks. Sandy or clayey substrates can also be found. Soils are chemically and physically homogeneous and contain high levels of organic material and carbon [28].

Landscape is dominated by Mediterranean mixed sclerophyllous forests that sit on the thermo and meso-Mediterranean belts. Vegetation is composed by evergreen trees, with predominance of holm oaks ( $Q$. ilex), cork oaks ( $Q$. suber) and phanerophyte communities of shrubs and bushes [29].

\subsection{Field Tasks}

Data relative to the damages by $C$. florentinus were taken between 2007 and 2017. Field work was carried out in two plots located in the Hornachuelos Natural Park, named "Los Lagares" and "Mezquitillas" (P1 and P2, respectively), where previously different levels of damage caused by $C$. florentinus had been quantified [30] [31]. The main environmental features of each plot (altitude, orientation, orography, surface, vegetal composition and coverage, tree density, and woodland age) are summarized in Appendix 1 (Table A1 and Table A2). Detailed information about the sampling dates, species of Quercus prospected and the respective number of trees examined at each sampling is provided in Table 1. At each sampling date and in each plot, 60 trees were randomly selected, geo-referenced, and carefully surveyed prior to assess damages by $\mathrm{C}$. florentinus (Table 1). A total of 612 holm oaks and 228 cork oaks were inspected for damage caused by $C$. florentinus along the overall period of monitoring.

Considering that age and density of oaks could affect the courses of damages produced by $C$. florentinus [11] [13], these parameters were also recorded when sampling was done. As it is accepted that the age of tree may be inferred from the diameter, the normal perimeter (measured at $1.30 \mathrm{~m}$ ) of all selected trees was taken [32] [33]. The age of tree was inferred from its diametric value, through the expression proposed by Plieninger et al. [34] for Q. ilex and by Montero and Cañellas [35] for Q. suber. The density of trees was estimated by the Closest Individual Method [36], because it allows appraising in non-delimited spaces.

Table 1. Sampling dates and number of Quercus ilex and Q. suber sampled in P1 (Los Lagares) and P2 (Mezquitillas) at each sampling year.

\begin{tabular}{ccccccc}
\hline \multirow{2}{*}{ Year } & \multicolumn{2}{c}{ Sampling date } & \multicolumn{2}{c}{ Number of trees sampled in P1 } & Number of trees sampled in P2 \\
\cline { 2 - 7 } & P1 & P2 & Q. ilex & Q. suber & Q. ilex & Q. suber \\
\hline 2007 & 7 June & 25 June & 60 & 0 & 30 & 30 \\
2008 & 2 May & 6 May & 52 & 8 & 42 & 18 \\
2009 & 16 June & 12 June & 60 & 0 & 25 & 35 \\
2010 & 6 May & 7 May & 38 & 22 & 27 & 33 \\
2012 & 12 June & 19 May & 43 & 17 & 42 & 18 \\
2013 & 20 June & 28 June & 48 & 12 & 58 & 2 \\
2017 & 9 June & 15 June & 48 & 12 & 39 & 21 \\
\hline
\end{tabular}


Data of environmental temperatures were obtained from the website of the Agriculture and Fisheries Council, Junta de Andalucía, Spain [37] (Appendix 2, Table A3).

Diagnosis of damage was made by observing the branches showing clear symptoms of current attack of the insect (yellowish leaves still bearing in the treetop). These branches are well distinguishable from those infected in preceding years because the older ones only conserve few, obscure, and dry leaves still hanging on the branch, or are totally defoliated, acquiring a singular aspect, easily recognizable on the canopy [8] [38] [39].

\subsection{Data Analysis}

To assess damage by $C$. florentinus, the following parameters were estimated [6] [11] [13]:

1) Infestation Level (IL): Percentage of trees damaged from the total sampled.

2) Population Intensity (PI): Average number of dry branches/damaged tree.

The following statistical tests were performed to evaluate the model bias.

The independent sample T-test was used to check differences between P1 and $\mathrm{P} 2$, relative to the tree density, the average diameter (independently for each Quercus species), and the IL and PI indices, considering the total sample of trees prospected in each sampling plot, along the complete sampling period. If the normality assumptions were not satisfied, after checking by the Shapiro-Wilk test, the equivalent non-parametric Mann-Whitney U/Wilcoxon Ranked Sum test was performed [40].

To explore relationships between tree age and damage (parameters IL and PI) or between tree density and damage (parameters IL and PI), the r-Pearson correlation coefficient was used for normally distributed variables. If not, the Spearman rank correlation coefficient was instead calculated.

To determine the fitting model for the relationship between the average environmental temperatures and damage (parameters IL and PI), a simple linear regression was performed, where $\mathrm{Y}$ was IL or IP as dependent variables and X was Temperature as predictor variable [41].

All statistical tests were conducted with $\alpha=0.05$.

Calculations were performed using SP Statistical Software (SPSS 20.0, 2011) and Past Software [42].

\section{Results}

\subsection{Analysis of the Starting Situation: Testing Differences between the Sampling Plots}

First of all, differences in the diameter of the trees sampled in P1 and P2 plots were checked, considering independently the samples of $Q$. suber and $Q$. ilex, because the difference in average size of them.

The results indicate that there are significant differences in the diameter of the holm oaks and the cork oaks sampled in plots $\mathrm{P} 1$ and $\mathrm{P} 2(\mathrm{Z}=-4.462, P=0 ; \mathrm{Z}=$ 
$-3.495, P=0$, respectively); corresponding to $\mathrm{P} 1$ the oldest trees in both species.

Differences in tree density between P1 and P2 were tested but considering the overall sample. On this case, the statistical test did not found significant differences $(\mathrm{T}=-0.671, P=0.515)$.

To complete the analysis, the parameters Infestation Level and Population Intensity were compared: regarding IL, the initial values corresponding to 2007 were higher in P2 (12.5) than in P1 (5.0); while there were non-significant differences in PI values of the two sampling plots $(\mathrm{T}=-1.798, P=0.097)$.

\subsection{Relationships between Tree Age, Density and Damage by $C$. florentinus}

To explore relationships between tree age and damages by $C$. florentinus correlations between the initial values (2007) of Infestation Level and Population Intensity of each sample and its respective average diameter were calculated, considering independently each oak species and sampling plot. Correlation values and their respective significance (Table 2) show non-significant correlation between tree diameter and damages by $C$. florentinus.

Correlation between the damage's indicator parameters and the density of the set of trees sampled in each plot (Table 3 ) resulted statistically significant only between Infestation Level and tree density in P1 plot.

\subsection{The Course of Damage over Time}

The course of the Infestation Level and the Population Intensity in the sampling plots (P1 and P2) in the period 2007-2017 are displayed in Figure 2(a) and

Table 2. The Pearson (r-P) or Spearman (r-S) correlation coefficient and probability $(P)$ between tree diamater and damages (IL and PI) by $C$. florentinus for each tree species (Quercus ilex and Q. suber) sampled in P1 (Los Lagares) and P2 (Mezquitillas). IL: Infestation Level; PI: Population Intensity.

\begin{tabular}{cccccc}
\hline \multirow{2}{*}{ Sampling Plot } & & \multicolumn{2}{c}{ IL } & \multicolumn{2}{c}{ PI } \\
\cline { 3 - 6 } & & $P$ & r-P/r-S & $P$ & r-P/r-S \\
\hline \multirow{2}{*}{ P1 } & Q. ilex & 0.349 & 0.419 & 0.221 & 0.530 \\
& Q. suber & 0.873 & 0.100 & 0.188 & 0.700 \\
& Q. ilex & 0.427 & -0.361 & 0.058 & -0.739 \\
P2 & Q. suber & 0.089 & 0.686 & 0.207 & 0.543 \\
\hline
\end{tabular}

Table 3. The Pearson correlation coefficient $(\mathrm{r}-\mathrm{P})$ and probability $(P)$ between damages (IL and PI) by $C$. florentinus and tree density in P1 (Los Lagares) and P2 (Mezquitillas). IL: Infestation Level; PI: Population Intensity; ${ }^{\star}$ indicates statistical significance.

\begin{tabular}{ccccc}
\hline & \multicolumn{2}{c}{ IL } & \multicolumn{2}{c}{ PI } \\
\cline { 2 - 5 } Sampling Plot & $P$ & r-P & $P$ & r-P \\
\hline P1 & $0.010^{*}$ & 0.877 & 0.160 & 0.594 \\
P2 & 0.630 & -0.224 & 0.208 & 0.543 \\
\hline
\end{tabular}


Figure 2(b), respectively. The trend lines show an increase in the Infestation Level which is more evident in P1 than in P2 plots, even though the initial infestation was higher in P2 than in P1 (subsection 3.1). The same effect is observed in the Population Intensity, although in this case the difference in the slope is attenuated being that the range of variation is lower.

If relationships between data of Infestation Level or Population Intensity with respect to the average annual temperature are fitted to a Linear Simple Regression Model (Figure 3), the " $r$ " statistic results positive and statistically significant in both sampling plots (Table 4).

\section{Discussion}

"As climate shifts, so do pests" [43]; to verify this statement in the particular case of $C$. florentinus in the southern of Iberian Peninsula summarizes the starting point of this research. In fact, it has been proved that changes in climate can

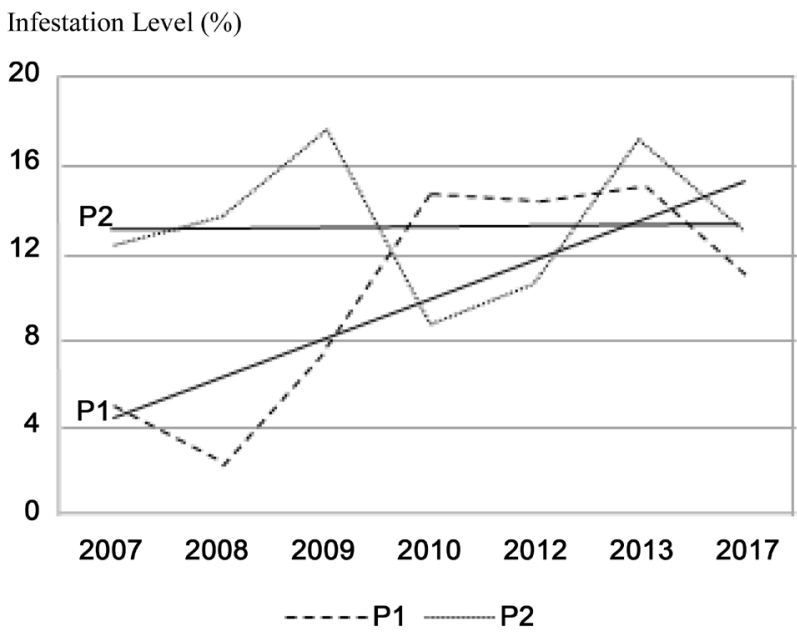

(a)

Population Intensity (Average value)

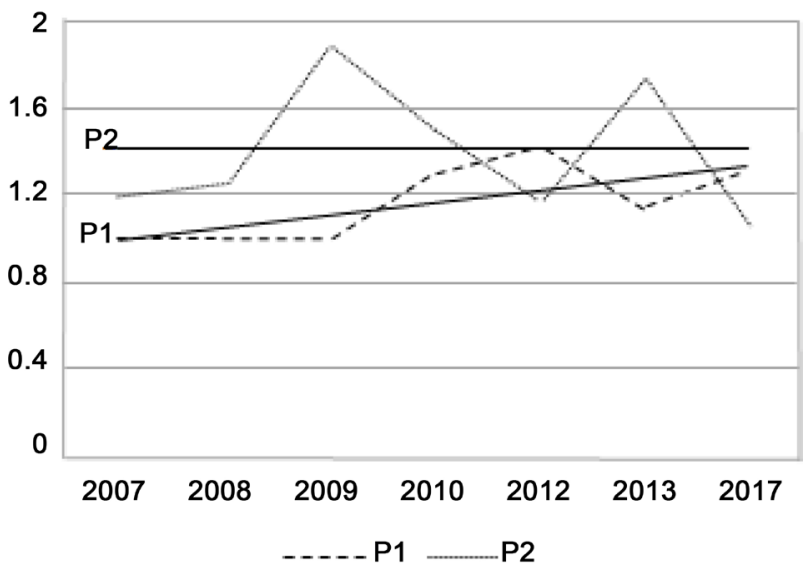

(b)

Figure 2. Temporal course of the Infestation Level (a) and the Population Intensity (b) and their respective trend lines during the monitoring period in P1 (Los Lagares) and P2 (Mezquitillas) sampling plots. 
P1 (Los Lagares)

Infestation Level (\%)

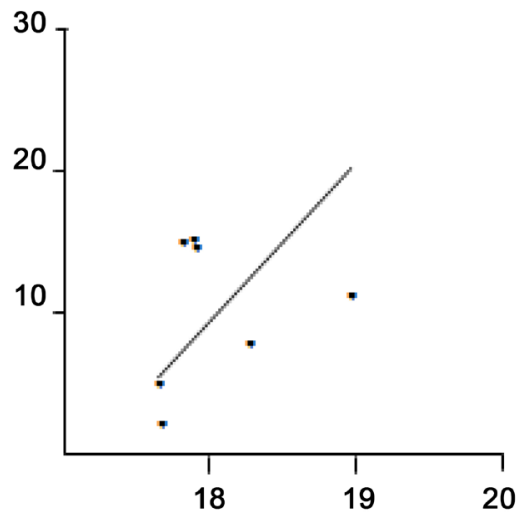

Average temperature $\left({ }^{\circ} \mathrm{C}\right)$
Population Intensity (Average value)

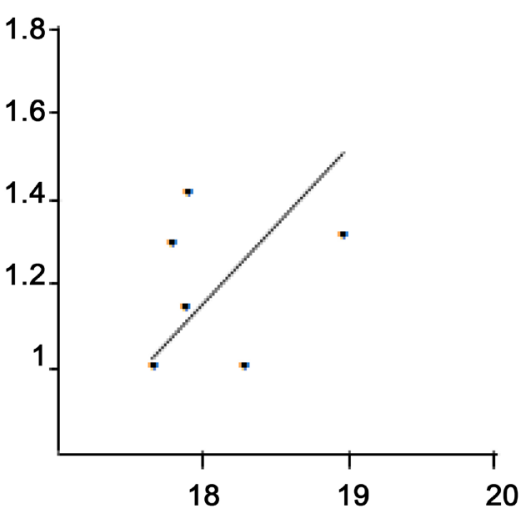

Average temperature $\left({ }^{\circ} \mathrm{C}\right)$

P2 (Mezquitillas)

Infestation Level (\%)

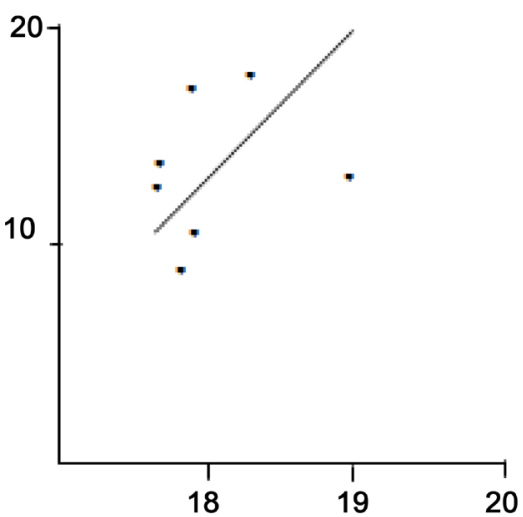

Average temperature $\left({ }^{\circ} \mathrm{C}\right)$
Population Intensity (Average value)

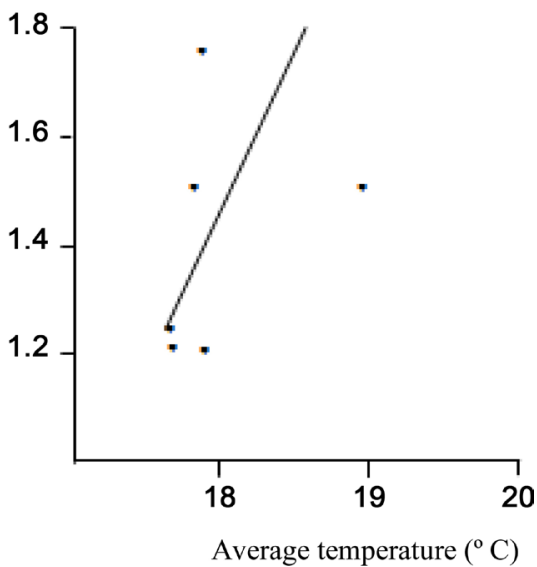

Figure 3. Fitted Linear Simple Regression Models showing relationship between the average environmental temperature and the parameters Infestation Level and Population Intensity in the $P 1$ (Los Lagares) and $P 2$ (Mezquitillas) sampling plots.

Table 4. Values of the Linear Regression coeficient $(r)$ and probablility $(P)$ between damage (Infestation Level: IL; Population Intensity: PI) and Annual Average Temperature $\left({ }^{\circ} \mathrm{C}\right)$ for each sampling plot (P1: Los Lagares; P2: Mezquitillas); ${ }^{*}$ indicates statistical significance.

\begin{tabular}{cccccc}
\hline \multirow{2}{*}{ Statistics values } & \multicolumn{5}{c}{ Linear Simple Regression } \\
\cline { 2 - 5 } & \multicolumn{5}{c}{$\mathrm{P} 1$} \\
$\mathrm{IL}$ & & $\mathrm{PI}$ & $\mathrm{IL}$ & $\mathrm{PI}$ \\
\hline $\mathrm{r}=$ & 0.196 & 0.334 & 0.198 & 0.395 \\
$P=$ & $0.014^{*}$ & $0.001^{\star}$ & $0.021^{\star}$ & $0.050^{\star}$ \\
\hline
\end{tabular}

influence distribution range and populations size of forest insects [44]. Temperature directly could affect rate of development, voltinism, population density, and extent of host plant exploitation and even the geographical distribution of this species [45]. In addition, it has been proven that shifts in temperature may 
also affects fitness and resistance of the host trees, which likewise impacts the progress of the damage in the forest [17].

Accordingly, prior to setting goals for environmental management it is necessary to assess the current situation of the area to be enhanced [45]. Trying to address this question, we look for the information relative to the effect of the climate change on the southern Iberian Peninsula. The last report from the International Panel on Climate Change [46] highlights the Mediterranean as one of the most vulnerable regions in the planet to be impacted by global warming. Simulations with impact models have shed some light on the risks and sensitivities to climate change, but they pose limitations when are applied at the regional scale and for low levels of warming [47].

Descending to the local scale of the studied area, we have verified significant thermal rising on the last decades. Indeed, the bioclimatic study of the Hornachuelos Natural Park, performed with data from the $60 \mathrm{~s}$ and $70 \mathrm{~s}$ [48], gave an average annual value of $16.8^{\circ} \mathrm{C}$, while if the period is extended to 1992 , the average annual temperature rises to $17.5^{\circ} \mathrm{C}$ [37].

Between 2000 and 2005, the average temperature for the area was $17.6^{\circ} \mathrm{C}$; and our data (Table A3 in Appendix 2) show average annual temperature ranging between $17.7^{\circ} \mathrm{C}$ in 2007 to $19.0^{\circ} \mathrm{C}$ in 2017 , which confirms the increasing trend at the local scale of the Hornachuelos Natural Park.

On the other hand, it should be paid attention to the direct influence of climate on the oaks species making up conforming the Mediterranean forests [19] [20] [21] [22] and on their pathogens and phytophagous insects [23] [24] [25] [26].

On the first of these issues, it is known that the oak's response to climate has varied in recent decades in Mediterranean areas as consequence of the increasing temperature and aridity [49]. Species like $Q$. ilex are likely to be most susceptible of suffering the negative effects of climate change [50] because increasing temperature without rising precipitation, intensifying ETP rates and water stress, which may prompt significant changes in the distribution of the species [19].

The second question to be considered is, in our case, the effect of thermic rising on the wood borer insects. Studies on some Buprestidae species (Agrilus sinuatus Olivier 1780, and A. sulcicollis Lacordaire 1835) [24] reveal that the geographical ranges have changed significantly as consequence of the climate change. Other research [51] found that the emerald ash borer ( $A$. planipennis Fairmaire 1888) shows great tolerance to wide ranges of high temperature. Regarding to $C$. florentinus, laboratory essays have highlighted faster development and enhanced survival at higher temperatures [5] [6] [26]. In addition, previous data [11] recorded also in the Hornachuelos Natural Park found infestation levels ranging from $3.02 \%$ to $9.80 \%$ in the period $1988-1993$ and between $3 \%$ and 5\% for 1991-1994 [12], in the same area. All these values are noticeably lower than those we found more than twenty years later. If the evolution of the insect populations is assessed by the course of the damage that it produces in the forest, 
the temperature increase found for the study area would be compatible with a significant increase in the parameters that allow quantifying their damages.

In fact, this happens: when the slope of the lines of the infestation levels of the last ten years is analyzed, an upward trend is detected that runs parallel to the thermal variation noticed. This result was verified after performing the linear regression between both parameters. Something similar, although quite less evident, occurs with the intensity of population.

This result may be interpreted as that the temperature favors the development of the populations of $C$. florentinus, but they do no concentrate damages in the same proportion. It tends to expand their occupancy area, infesting more trees. This may also explain that the level of infestation has increased less in the plot where more damage was initially quantified, and it is compatible with the expansion predicted in the models developed [17] to explicate the immigration of C. florentinus towards regions of Central Europe.

According to our results, other environmental factors, as the age of the trees, seem to be less significant on the course of the pest on the research area. Nevertheless, results relative to relationships between damage and tree density is significant in the plot P1 "Los Lagares". On this regard, it is known that stand density could attenuate the response to climate by smoothing extreme conditions. But, nevertheless, the effect of competition might reverse this positive influence at individual level. It has been suggested that reduction of density by thinning could increase the individual resistance to drought stress and that this differential response varies with climatic shifts [52] [53]. As the detailed study of these effects on the Quercus species studied has not been addressed in the present work, more research is necessary to make a more whole interpretation of the results.

\section{Conclusion}

In conclusion, based on the current results and those of prior research, it can be stated that there has been a local thermal increase that has affected the populations of $C$. florentinus in the southern Iberian Peninsula, extending their damage but not intensifying them significantly. The foreseeable spreading of the insect on the future climate scenarios makes necessary the implementation of effective control activities, as selective pruning [6], in the management of Mediterranean oak forests, as a preventive measure to avoid the demographic explosion of this pest.

\section{Acknowledgements}

The authors are grateful to ACUAES (Aguas de la Cuenca de España, S.A., Ministry of Agriculture, Food and Environment, Government of Spain) and Ingeniería y Gestión del Sur, S.L. (Grupo IG-IPA) for the financial support and graduate Mr. Juan Rafael Carbonero for his assistance in formal aspects of the manuscript. 


\section{References}

[1] Thompson, I.D., Guariguata, M.R., Okabe, K., Bahamondez, R., Nasi, R., Heymell, V. and Sabogal, C. (2013) An Operational Framework for Defining and Monitoring Forest Degradation. Ecology and Society, 18, 20. https://doi.org/10.5751/ES-05443-180220

[2] Modica, G., Merlino, A., Solano, F. and Mercurio, R. (2015) An Index for the Assessment of Degraded Mediterranean Forest Ecosystems. Forest Systems, 24, 3-13. https://doi.org/10.5424/fs/2015243-07855

[3] Moyano, L., Cárdenas, A.M., Gallardo, P. and Presa, J.J. (2014) Short-Term Effects of a Revegetation Program on the Orthopteran Diversity in Oak Forests of the Southern Iberian Peninsula. Journal of Insect Science, 14, 1-14. https://doi.org/10.1093/jisesa/ieu152

[4] Sandoval, A. and Quiñonez, M. (2007) La Presa de la Breña II. Revista de Obras Públicas, 154, 179-194.

[5] Cárdenas, A.M. and Gallardo, P. (2012) The Effect of Temperature on the Preimaginal Development of the Jewel Beetle Coraebus florentinus (Coleoptera: Buprestidae). European Journal of Entomolgy, 109, 21-28. https://doi.org/10.14411/eje.2012.004

[6] Gallardo, P., Cárdenas, A.M. and Soriano, J.M. (2018) Long-Term Assessment of Selective Pruning of Quercus Species for Controlling Populations of Coraebus florentinus (Coleoptera: Buprestidae) in Mediterranean Forests. Forests, 9, 1-14. https://doi.org/10.3390/f9020049

[7] Fürstenau, B., Rosell, G., Guerrero, A. and Quero, C. (2012) Electrophysiological and Behavioral Responses of the Black-Banded Oak Borer, Coroebus florentinus, to Conspecific and Host-Plant Bolatiles. Journal of Chemical Ecology, 38, 378-388. https://doi.org/10.1007/s10886-012-0110-1

[8] Jurc, M., Bojovic, S., Komjanc, B. and Krč, J. (2009) Xylophagous Entomofauna in Branches of Oaks (Quercus spp.) and Its Significance for Oak Health in the Karst Region of Slovenia. Biologia, 64, 130-138. https://doi.org/10.2478/s11756-009-0024-8

[9] Bachiller, P., Cadahia, D., Ceballos, G., Ceballos, P., Cobos, J.M., Cuevas, O., Dafauce, C., Dávila, J., González, J.R., Hernández, R., Ledesma, L., Mallen, J.M., Molina, J., Montoya, R., Neira, M., Obama, E., Riesgo, A., Robedo, F., Romanyk, N., Rupérez, A., Sánchez, A., Soria, S., Toimil, F.J. and Torrent, J.A. (1981) Plagas de Insectos en las Masas Forestales Españolas. Ministerio de Agricultura, Pesca y Alimentación, Madrid.

[10] Montoya, J.M. (1988) Los Alcornocales. Ministerio de Agricultura, Pesca y Alimentación, Madrid.

[11] Soria, F.J. and Ocete, M. (1993) Estudios Poblacionales Sobre Coroebus florentinus (Herbst) (Col. Buprestidae). Boletín de Sanidad Vegetal: Plagas, 19, 27-35.

[12] Fernández de Cordova, J. and Cabezuelo, P. (1995) La "Seca de Ramillas" o "Banderas" de la Encina (Coroebus florentinus Herbst). Distribución Biológica y Lucha Mecánica en la Provincia de Córdoba. Phytoma España, 71, 31-37.

[13] Lombardero, M.J. and Fernández de Ana Magán, F.J. (1996) Distribución y Daños de Coroebus florentinus (Herbst) (Col., Buprestidae) en Galicia (NO de la Península Ibérica). Ecología, 10, 499-508.

[14] Evans, H.F., Moral, L.G. and Pajares, J.A. (2004) Biology, Ecology and Economic Importance of Buprestidae and Cerambycidae. In: Lieutier, F., Day, R.K., Battisti, 
A., Gregoire, J.C. and Evans, F.H., Eds., Bark and Wood Boring Insects in Living Trees in Europe, a Synthesis, Kluwer Academic Publishers, Dordrecht, The Netherlands, 447-474. https://doi.org/10.1007/978-1-4020-2241-8_20

[15] Cobos, A. (1986) Fauna Ibérica de Coleópteros Bupréstidos. Consejo Superior de Investigaciones Científicas, Madrid.

[16] Verdugo, A. (2005) Fauna de Bupréstidos de la Península Ibérica y Baleares. Argania Edition, Barcelona.

[17] Buse, J., Griebeler, E.M. and Niehuis, M. (2013) Rising Temperatures Explain Past Immigration of the Thermophilic Oak-inhabiting Beetle Coraebus florentinus (Coleoptera: Buprestidae) in South-West Germany. Biodiversity and Conservation, 22, 1115-1131. https://doi.org/10.1007/s10531-012-0395-y

[18] Sallé, A., Nageleisen, L.M. and Lieutier, F. (2014) Bark and Wood Boring Insects Involved in Oak Declives in Europe: Current Knowledge and Future Prospects in a Context of Climate Change. Forest Ecology and Management, 328, 79-93. https://doi.org/10.1016/j.foreco.2014.05.027

[19] Benito Garzón, M., Sánchez de Dios, R. and Sainz Ollero, H. (2008) Effects of Climate Change on the Distribution of Iberian Tree Species. Applied Vegetation Science, 11, 1-10. https://doi.org/10.3170/2008-7-18348

[20] Gea-Izquierdo, G., Martín-Benito, D., Cherubini, P. and Cañellas, I. (2009) Climate-Growth Variability in Quercus ilex West Iberian Open Woodlands of Different Stand Density. Annals of Forest Science, 66, 802-812. https://doi.org/10.1051/forest/2009080

[21] Patón, D., García-Herrera, R., Cuenca, J., Galavis, M. and Roig, A. (2009) Influence of Climate on Radial Growth of Holm Oaks (Quercus ilex subsp. ballota Desf) from SW Spain. Geochronometria, 34, 49-56. https://doi.org/10.2478/v10003-009-0017-1

[22] Navarro, R., Fernández-Cancio, A. and Herranz, O. (2007) The Vitality of Cork and Holm Oak Stands and Forests. Report on the Évora Conference Meeting, Lisbon.

[23] Ayres, M.P. and Lombardero, M.J. (2000) Assessing the Consequences of Global Change for Forest Disturbance from Herbivores and Pathogens. Science of the Total Environment, 262, 263-286. https://doi.org/10.1016/S0048-9697(00)00528-3

[24] Alexander, K. (2003) Changing Distributions of Cantharidae and Buprestidae within Great Britain (Coleoptera). Proceedings of the 13 th International Colloquium of the European Invertebrate, Leiden, 87-91.

[25] Buse, A. and Good, J.E.G. (1996) Synchronization of Larval Emergence in Winter Moth (Operophtera brumata L.) and Budburst in Pedunculated oak (Quercus robur L.) Under Simulated Climate Change. Ecological Entomology, 21, 335-343. https://doi.org/10.1046/j.1365-2311.1996.t01-1-00001.x

[26] Bale, J.S., Masters, G.J., Hodkinson, I.D., Awmack, C., Bezemer, T.M., Brown, V.K., Butterfield, J., Buse, A., Coulson, J.C, Farrar, J., Good, J.E.G., Harrington, R., Hartley, S., Jones, T.H., Lindroth, R.L., Press, M.C., Symrnuiydus, I., Watt, A.D. and Whittaker, J.B. (2002) Herbivory in Global Climate Change Research: Direct Effects of Rising Temperature on Insect Herbivores. Global Change Biology, 8, 1-16. https://doi.org/10.1046/j.1365-2486.2002.00451.x

[27] Blanco, R. (2006) Parque Natural Sierra de Hornachuelos. Junta Rectora Parque Natural Sierra de Hornachuelos, Sevilla.

[28] Pinilla, R. (2006) Plan de Ordenación de Recursos Naturales. Plan Rector de Uso y Gestión del Parque Natural de la Sierra de Hornachuelos. Consejería de Medio Ambiente, Junta de Andalucía, Sevilla. 
[29] Cárdenas, A.M. and Bach, C. (1989) The Effect of Some Abiotic Factors on the Distribuition and Selection of Habitat by the Carabid Beetles in the Central Sierra Morena Mountains (SW Córdoba, Spain). Vie Milieu, 39, 93-103.

[30] Gallardo, P. (2011) Incidencia de Coleópteros Perforadores en Formaciones de Quercíneas del Suroeste Peninsular: Evaluación de Daños y Propuestas Para la Conservación. PhD Thesis, University of Córdoba, Córdoba.

[31] Cárdenas, A.M. and Gallardo, P. (2013) The Effects of Oviposition Site on the Development of the Wood Borer Coraebus florentinus (Coleoptera: Buprestidae). European Journal of Entomology, 110, 135-144. https://doi.org/10.14411/eje.2013.019

[32] Montes, C. and Ramírez, L. (1978) Descripción y Muestreo de Poblaciones y Comunidades Vegetales y Animales. Publicaciones Universidad de Sevilla, Sevilla.

[33] Orozco, M.F. (1982) Producción Forestal. Editorial Trillas, México.

[34] Plieninger, T., Pulido, F.J. and Konold, W. (2003) Effects of Land Use History on Size Structure of Holm Oak Stands in Spanish Dehesas: Implications for Conservation and Restoration. Environmental Conservation, 30, 61-70. https://doi.org/10.1017/S0376892903000055

[35] Del Río, M., Montes, F., Cañelas, I. and Montero, G. (2003) Revisión: Índices de Madera y Bosques. Investigación Agraria: Sistemas y Recursos Forestales, 12, 159-176.

[36] Henderson, P.A. (2003) Practical Methods in Ecology. Blackwell Publishing, Oxford.

[37] Agriculture and Fisheries Council, Junta de Andalucía, Spain. http://www.juntadeandalucia.es/agriculturaypesca/ifapa

[38] Solinas, M. (1971) Considerazioni Ecologiche Sul Preoccupante Sviluppo Di Coroebus florentinus (Herbst) Nelle Leccete del Gargano. Entomologica, 7, 115-121.

[39] Brechtel, F. and Kostenbader, H. (2002) Die Pracht-und Hirschkäfer Baden-Württembergs. Ulmer, Stuttgart.

[40] Zar, J.H. (1999) Biostatistical Analysis. Prentice Hall, Upper Saddle River, New York.

[41] Rencher, A.C. and Schaalje, G.B. (2007) Simple Linear Regression in Linear Models in Statistics. John Wiley \& Sons, Inc., Hoboken, New York.

[42] Hammer, Ø., Harper, D.A.T. and Ryan, P.D. (2001) PAST: Paleontological Statistics Software Package for Education and Data Analysis. Palaeontologia Electronica, 4, 1-9.

[43] Young, S.L. (2017) As Climate Shifts, So Do Pests: A National Forum and Assessment. Bulletin of the Ecological Society of America, 98, 165-172. https://doi.org/10.1002/bes2.1315

[44] Liebhold, A. and Bentz, B. (2011) Insect Disturbance and Climate Change. U.S. Department of Agriculture, Forest Service, Climate Change Resource Center.

[45] Hobbs, R. (2003) Ecological Management and Restoration: Assessment, Setting Goals and Measuring Success. Ecological Management and Restoration, 4, 1-3.

[46] Stocker, T.F., Qin, D., Plattner, G.K., Alexander, L.V., Allen, S.K., Bindoff, N.L., Bréon, F.M., Church, J.A., Cubasch, U., Emori, S., Forster, P., Friedlingstein, P., Gillett, N., Gregory, J.M., Hartmann, D.L., Jansen, E., Kirtman, B., Knutti, R., Krishna, K., Lemke, P., Marotzke, J., Masson-Delmotte, V., Meehl, G., AMokhov, I.I., Piao, S., Ramaswamy, V., Randall, D., Rhein, M., Rojas, M., Sabine, C., Shindell, D., Talley, L.D., Vaughan, D.G. and Xie, S.P. (2013) Summary for Policymakers. In: 
Stocker, T.F., Qin, D., Plattner, G.K., Tignor, M., Allen, S.K., Boschung, J., Nauels, A., Xia, Y., Bex, V. and Midgley, P.M. Eds., Climate Change: The Physical Science Basis. Contribution of Working Group I to the Fifth Assessment Report of the Intergovernmental Panel on Climate Change, Cambridge University Press, Cambridge and New York.

[47] Guiot, J. and Cramer, W. (2016) Climate Change: The 2015 Paris Agreement Thresholds and Mediterranean Basin Ecosystems. Science, 354, 465-468.

https://doi.org/10.1126/science.aah5015

[48] Cárdenas, A.M. (1983) Estudio climático del área circundante al Embalse del Bembézar (Córdoba). VIII Reunión de Bioclimatología, Zaragoza, 109-117.

[49] D’Arrigo, R., Wilson, R., Liepert, B. and Cherubini, P. (2008) On the "Divergence Problem" in Northern Forests: A Review of the Treering Evidence and Possible Causes. Global Planet Change, 60, 289-305. https://doi.org/10.1016/j.gloplacha.2007.03.004

[50] Sumner, G.N., Romero, R., Homar, V., Ramis, C., Alonso, S. and Zorita, E. (2003) An Estimate of the Effects of Climate Change on the Rainfall of Mediterranean Spain by the Late Twenty First Century. Climate Dynamics, 20, 789-805. https://doi.org/10.1007/s00382-003-0307-7

[51] Myers, S.W., Fraser, I. and Mastro, V.C. (2009) Evaluation of Heat Treatment Schedules for Emerald Ash Borer (Coleoptera: Buprestidae). Journal of Economic Entomology, 102, 2048-2055. https://doi.org/10.1603/029.102.0605

[52] Misson, L., Nicault, A. and Guiot, J. (2003) Effects of Different Thinning Intensities on Drought Response in Norway Spruce (Picea abies (L.) Karst.). Forest Ecology and Management, 183, 47-60. https://doi.org/10.1016/S0378-1127(03)00098-7

[53] Moreno, G. and Cubera, E. (2008) Impact of Stand Density on Water Status and Leaf Gas Exchange in Quercus ilex. Forest Ecology and Management, 254, 74-84. https://doi.org/10.1016/j.foreco.2007.07.029 


\section{Appendix 1}

Table A1. Environmental features of the plot P1 (Los Lagares): surface, orography, orientation, altitude, vegetal composition, coverage, tree density and woodland age.

\begin{tabular}{|c|c|}
\hline \multicolumn{2}{|r|}{ P1 (Los Lagares) } \\
\hline Average surface & $1.82 \mathrm{ha}$ \\
\hline Orography & Hillside with medium slope \\
\hline Orientation & South \\
\hline Average altitude & $426 \mathrm{~m}$ \\
\hline Shrub composition & $\begin{array}{l}\text { Cistus sp. L., Phlomis purpurea L., Lavandula stoechas L., } \\
\text { Rubus ulmifolius Schott, Daphne gnidium L., Genista hirsuta Vahl., } \\
\text { Pistacia lentiscus L., Rosmarinus officinalis L. }\end{array}$ \\
\hline Canopy cover fraction & $25 \%-50 \%$ \\
\hline $\begin{array}{l}\text { Average woodland } \\
\text { composition }\end{array}$ & $\begin{array}{l}\text { Quercus ilex L. }(\approx 80 \%) \text { and Q. suber L. }(\approx 20 \%) \text {. Pure forest of holm } \\
\text { oaks }\end{array}$ \\
\hline Average density woodland & 60 trees/ha \\
\hline Woodland age & $\begin{array}{l}\text { Average diameter } Q . \text { ilex }=35.99 \pm 3.56 \mathrm{~cm} \\
\text { Average diameter } Q . \text { suber }=60.59 \pm 10.13 \mathrm{~cm}\end{array}$ \\
\hline $\begin{array}{l}\text { Table A2. Environment } \\
\text { orientation, altitude, vege }\end{array}$ & $\begin{array}{l}\text { al features of the plot P2 (Mezquitillas): surface, orography, } \\
\text { tal composition, coverage, tree density and woodland age. }\end{array}$ \\
\hline \multicolumn{2}{|r|}{ P2 (Mezquitillas) } \\
\hline Average surface & $1.40 \mathrm{ha}$ \\
\hline Orography & Hillside with low/medium slope \\
\hline Orientation & South \\
\hline Average altitude & $541 \mathrm{~m}$ \\
\hline Shrub composition & $\begin{array}{c}\text { Cistus sp., P. purpurea, } R \text {. ulmifolius, D. gnidium, G. hirsuta, P. lentiscus, } \\
\text { Hedera helix L., L. stoechas, Smilax aspera L., R. officinalis L., Nerium } \\
\text { oleander L. }\end{array}$ \\
\hline Canopy cover fraction & $25 \%-50 \%$ \\
\hline $\begin{array}{l}\text { Average woodland } \\
\text { composition }\end{array}$ & Q. ilex $(\approx 90 \%)$ and $Q$. suber $(\approx 10 \%)$. Pure forest of holm oaks \\
\hline Average density woodland & 80 trees $/$ ha \\
\hline Woodland age & $\begin{array}{l}\text { Average diameter } Q . \text { ilex }=31.06 \pm 6.01 \mathrm{~cm} \\
\text { Average diameter } Q . \text { suber }=52.84 \pm 11.31 \mathrm{~cm}\end{array}$ \\
\hline
\end{tabular}

\section{Appendix 2}

Table A3. Average of maximum, minimum and mean temperatures $\left({ }^{\circ} \mathrm{C}\right)$ of the research area during the sampling period.

\begin{tabular}{cccccccccccc}
\hline & \multicolumn{10}{c}{ Sampling period } \\
\cline { 2 - 12 } Average temperature & 2007 & 2008 & 2009 & 2010 & 2011 & 2012 & 2013 & 2014 & 2015 & 2016 & 2017 \\
\cline { 2 - 12 } & 24.8 & 24.4 & 25.3 & 24.2 & 25.5 & 25.1 & 24.5 & 25.3 & 25.8 & 25.0 & 26.5 \\
Maximum & 11.6 & 11.7 & 11.9 & 12.0 & 12.6 & 11.6 & 11.9 & 12.6 & 12.0 & 12.4 & 12.3 \\
Minimum & 17.7 & 17.7 & 18.3 & 17.8 & 18.5 & 17.9 & 17.9 & 18.5 & 18.5 & 18.4 & 19.0 \\
\hline
\end{tabular}

